\title{
Discussion on project output and satisfaction evaluation of public expenditure and budget performance evaluation of urban public green space maintenance based on AHP
}

\author{
WANG Lan ${ }^{1, a}$, ZHANG Lei ${ }^{2, b}$ \\ ${ }^{1}$ Art and Design college, Shanghai Sanda University, Shanghai, Pudong New Area 20120, China \\ ${ }^{2}$ Shanghai K\&Z Construction Project Management Co.,Ltd

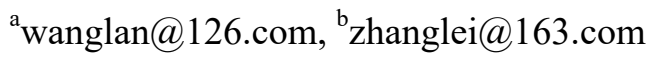

Keywords: Public green space, financial performance, project output, satisfaction.

\begin{abstract}
City green space can improve the ecological environment, beautify the city, improve the city's image and taste, the landscape construction of the city's local government as an important task, how to evaluate the public green maintenance expenditure, with the objective of practical significance.

Judging from the actual situation, the evaluation of the quality and effectiveness of public green space maintenance is not reasonable, and this evaluation mechanism does not allow the "customer" to participate. On the basis of drawing on the existing research results, this paper combines the cost benefit method and factor analysis method based on AHP. The balance between the focus on financial investment and maintenance effect so as to explore the different standard of maintenance funds can ensure seedling growth, maintain good landscape effect of project output, can obtain better satisfaction etc.
\end{abstract}

\section{Introduction}

(1) The rapid expansion of urban public green space

With the development of social economy and the increase of population, the living environment is becoming worse and worse. Governments around the city garden construction as an important task, and vigorously carry out the creation of garden style, garden type eco city and other special activities. The area of urban public green space is expanding, and the maintenance task is increasing rapidly.

(2)The particularity of urban green space maintenance;

There are essential differences between landscaping and other projects. Conservation is a long and complex systematic project, [1]. The construction and management of city public space mostly rely on government financial support, to further improve the level of urban public green space maintenance and quality, Shanghai from 2006 began to try the operation of the market reform of urban public green maintenance management, and achieved certain results. But many city public green maintenance implementation of "separation of management and maintenance" mode, is a focus on investment funds "process management", while ignoring the "money effect" results management; the second is the competent department in charge of internal evaluation. The right to evaluate is in the hands of the maintenance authorities and belongs to "internal evaluation", which does not allow the "customer" to participate. The performance evaluation of the special subsidy for afforestation and maintenance is the key to solve this problem.

(3)The importance of project output and satisfaction evaluation to performance evaluation

In the performance evaluation on project output and public satisfaction evaluation is an important part of city green space maintenance financial performance management, "a concept embodied the three" [2] oriented management theory, "customer service" theory, but also improve the city public green maintenance level tube effective path; case study in this paper the weights of evaluation 
indexes, the values shown in Table 1-1 also validates the importance evaluation of project output and satisfaction on performance.

\section{Research status}

Maintenance of green spaces is one of the billions of dollars in public spending. In 1906, Bruere et al established Municipal Research Bureau in the United States, began to study the performance evaluation of government, creating a precedent for the public sector performance evaluation 3 , after 100 years of development, has formed a lot of valuable experience, such as construction based on multi subject system dominated by the government of 360 degree performance appraisal method, in order to improve customer satisfaction the pursuit of value, praised the performance management of the "3E" model, focusing on the use of KPI to design the performance evaluation index system, the balanced scorecard has been widely used 4. In China, scholars Xu Yixin, Lu static 5, 6, Xu Chenyang, Wang Huamei 7, Zhu Zhigang 8, explored 9 of public fiscal expenditure performance evaluation index system and the principle of hierarchy, etc.. Ma Guoxian put forward the "performance management view on" 10, Ouyang Huasheng with an example of city road maintenance funds performance evaluation, 11, 12 etc.. In June 22, 2009, the Ministry of Finance promulgated the Interim Measures for the performance evaluation of fiscal expenditure, which was used to standardize and guide the performance evaluation of local finance [13]. Subsequently, Zhejiang and Shanghai districts began to evaluate the performance of public expenditure. These theories and practice research are beneficial exploration of performance evaluation management, and provide theoretical support for this study.

As for public green space studies, as of 2017, there were more than 10000 records in china. These studies are mainly from the perspective of landscape planning and design, ecology, conservation issues, land use, research on performance evaluation of government investment of public green space maintenance is relatively small: in $2010 \mathrm{Jia} \mathrm{Hu}$, a case study of Shanghai city landscape greening in government investment projects performance evaluation system is studied, although there is some reference value, but in green conservation performance evaluation has many difficulties in the actual operation. In 2010, Chen Yujie pointed out the specific content of the performance evaluation index system of urban green construction expenditure [14]. In 2015, Tang Zilai, Gu Shu on the social performance evaluation from 15 regional equity to social justice in Shanghai city public green space distribution. In 2016, Yang Huaiyu built a government investment project performance evaluation index system based on the practice of garden greening in Guangzhou University city. [16]. These studies are targeted, but mainly from the perspective of construction, green maintenance expenditure performance evaluation is difficult to apply.

At present, domestic scholars have not a balance between fiscal expenditure budget and green conservation effect for research, for green space maintenance, there is a lack of good service, to provide green maintenance funds can improve the ecological and landscape maintenance projects such as seedling output, in-depth research can make users satisfied with the. Too little maintenance input will slow down the existing green landscape resources; excessive input will lead to waste of financial and tax resources. Therefore, performance budgeting and evaluation index, project output and user satisfaction, cost and benefit analysis of the financial expenditure of maintenance funds can be better, improve the regulatory level of government departments on greening maintenance funds, to guide the work of garden workers, the results of the project will have very important practical application value.

\section{The process of research [12]}

\section{Evaluation methods and basic indicators system}

In June 22, 2009, the Ministry of Finance issued the "Interim Measures for the management of financial expenditure performance evaluation" (FB [2009]76) [17] is put forward to analyze the cost benefit analysis method, comparison method, factor method, minimum cost by four methods. This paper expounds the city public green maintenance budget and fiscal expenditure performance 
evaluation reference Ouyang Huasheng with research methods of performance evaluation example of maintenance funds of City Road, the cost - benefit method and factor analysis method, combined with the practice of public green maintenance expenditure and budget performance evaluation in a district of the city, through the collection of the evaluation index the data and standards, and conduct social surveys, based on AHP, experts discussed evaluation factors and weight assignment, get the specific evaluation results.

The index system consists of input management, process management, project output, satisfaction, 4 first level indicators, 11 two level indicators and 21 three level indicators.

\section{Based on AHP, to determine the index weight}

The determination of the index weight is very important in the performance evaluation index system. On the basis of Delphy Fa, this study uses AHP to do consistency test, and finally determine the weight of the index. Through the questionnaire survey of 10 experts, the relative importance of each index is determined to determine the weight of the index. In the full understanding of the analytic hierarchy process based on AHP software AHP model is established according to the index system, and then check the correctness of the model, and establishes a hierarchical structure to complete the steps that have been completed by AHP.

The second step is the calculation of the weights among the different levels. The importance of each element comparison value mainly adopts simulation of Delphi method, the expert "back-to-back" average and summary views. On the basis of generating hierarchical model chart, the index system of urban public green space maintenance performance evaluation index is established and the weight assessment questionnaire is derived. Hand over the questionnaire to 10 experts at the same time. After the arithmetic average of the result, the comparison of the importance of different factors at the same level is obtained. The value of input level analysis software, because of the importance of software is just 1 - 9 integer values between, if there is a decimal to four pieces of five entry into the way comparison value, then consistency verification.

\section{The establishment of evaluation system (Table 1.1)}

Through the study of the above indicators, it is found that the output and satisfaction of urban public green space are individual indicators, and there are many differences with other financial performance evaluation, this paper focuses on this part. Table 1 neglected input management and process management two, three indicators. 
Table 1 performance evaluation index system of urban public green space expenditure in Shanghai

\begin{tabular}{|c|c|c|c|c|c|c|}
\hline $\begin{array}{l}\text { First level } \\
\text { index }\end{array}$ & $\begin{array}{c}\text { Two } \\
\text { level index }\end{array}$ & $\begin{array}{c}\text { Three } \\
\text { level index }\end{array}$ & $\begin{array}{l}\text { Sco } \\
\text { re }\end{array}$ & Index Interpretation & $\begin{array}{l}\text { Scoring } \\
\text { standard }\end{array}$ & Remarks \\
\hline $\begin{array}{c}\text { A input } \\
\text { management }\end{array}$ & ellipsis & ellipsis & 15 & ellipsis & ellipsis & $\begin{array}{l}\text { common } \\
\text { measures }\end{array}$ \\
\hline $\begin{array}{c}\mathrm{B} \text { input } \\
\text { management }\end{array}$ & ellipsis & ellipsis & 9 & ellipsis & ellipsis & $\begin{array}{l}\text { common } \\
\text { measures }\end{array}$ \\
\hline \multirow[t]{8}{*}{$\begin{array}{l}\text { C project } \\
\text { output }\end{array}$} & & & 39 & & & $\begin{array}{l}\text { Personalit } \\
\mathrm{y} \text { index }\end{array}$ \\
\hline & $\begin{array}{l}\mathrm{C} 1 \\
\text { maintenanc } \\
\text { e completed }\end{array}$ & $\begin{array}{l}\text { C11 lawn } \\
\text { mowing } \\
\text { conservation } \\
\text { plan } \\
\text { completion } \\
\text { rate } \\
\end{array}$ & 3 & $\begin{array}{l}\text { Comprehensive evaluation } \\
\text { according to relevant } \\
\text { management system, work } \\
\text { plan and assessment }\end{array}$ & ellipsis & \\
\hline & & $\begin{array}{c}\text { C12 } \\
\text { flowering } \\
\text { shrubs } \\
\text { pruning plan } \\
\text { completion } \\
\text { rate. } \\
\end{array}$ & 3 & $\begin{array}{l}\text { Comprehensive evaluation } \\
\text { according to relevant } \\
\text { management system, work } \\
\text { plan and assessment }\end{array}$ & ellipsis & \\
\hline & & $\begin{array}{l}\text { C13 } \\
\text { pruning rate } \\
\text { of roadside } \\
\text { trees; } \\
\text { completion } \\
\text { rate } \\
\end{array}$ & 3 & $\begin{array}{l}\text { Comprehensive evaluation } \\
\text { according to relevant } \\
\text { management system, work } \\
\text { plan and assessment }\end{array}$ & ellipsis & \\
\hline & & $\begin{array}{l}\mathrm{C} 14 \text { the } \\
\text { reasonable } \\
\text { level of } \\
\text { maintenance } \\
\text { standards }\end{array}$ & 4 & $\begin{array}{c}\text { The matching degree } \\
\text { between the maintenance } \\
\text { standards and the classification } \\
\text { standards of Shanghai } \\
\text { landscaping made by the } \\
\text { Municipal Greening } \\
\text { Administration }\end{array}$ & ellipsis & \\
\hline & $\begin{array}{l}\mathrm{C} 2 \\
\text { maintenanc } \\
\text { e technical } \\
\text { index status }\end{array}$ & $\begin{array}{l}\text { C21 } \\
\text { scenic spots } \\
\text { and scenic } \\
\text { road } \\
\text { preservation } \\
\text { rate }\end{array}$ & 5 & $\begin{array}{l}\text { Comprehensive assessment } \\
\text { of the existing landscape road } \\
\text { number / original landscape } \\
\text { road number, the number of } \\
\text { existing scenic spots / the } \\
\text { original number of beautiful } \\
\text { attractions }\end{array}$ & ellipsis & \\
\hline & & $\begin{array}{l}\text { C22, } \\
\text { green } \\
\text { landscape, } \\
\text { good rate }\end{array}$ & 9 & $\begin{array}{l}\text { According to the relevant } \\
\text { management system and } \\
\text { evaluation standard for } \\
\text { evaluation of the } \\
\text { comprehensive evaluation, the } \\
\text { public green area assessment } \\
\text { (landscape, plant growth, } \\
\text { maintenance and management, } \\
\text { the green quantity) a total of } \\
100 \text { points, the score included } \\
\text { in the assessment of green } \\
\text { accounting for } 85 \% \text { of the } \\
\text { number of green space more } \\
\text { than } 85 \text { points. }\end{array}$ & ellipsis & \\
\hline & & $\begin{array}{l}\text { C23 } \\
\text { roadside tree } \\
\text { survival rate }\end{array}$ & 3 & $\begin{array}{l}\text { According to the relevant } \\
\text { management system and } \\
\text { assessment, the total number of } \\
\text { existing trees / the total } \\
\text { number of existing trees was } \\
\text { assessed }\end{array}$ & ellipsis & \\
\hline
\end{tabular}




\begin{tabular}{|c|c|c|c|c|c|}
\hline & & $\begin{array}{l}\mathrm{C} 24 \\
\text { roadside } \\
\text { trees, } \\
\text { appearance, } \\
\text { good rate }\end{array}$ & 6 & $\begin{array}{l}\text { According to the relevant } \\
\text { management system and } \\
\text { evaluation standard for } \\
\text { evaluation of the } \\
\text { comprehensive evaluation, the } \\
\text { public green area assessment } \\
\text { (including growth, crown, } \\
\text { trunk, tree) a total of } 100 \\
\text { points, the score included in } \\
\text { the assessment of green } \\
\text { accounting for } 80 \% \text { of the } \\
\text { number of green space more } \\
\text { than } 80 \text { points. }\end{array}$ & ellipsis \\
\hline & & $\begin{array}{c}\text { C25 } \\
\text { innovation } \\
\text { and } \\
\text { management } \\
\text { capabilities } \\
\text { (technical } \\
\text { innovations } \\
\text { (litter } \\
\text { recovery, } \\
\text { etc)) }\end{array}$ & 3 & $\begin{array}{l}\text { Comprehensive evaluation } \\
\text { according to relevant } \\
\text { management, innovation } \\
\text { system and assessment. }\end{array}$ & ellipsis \\
\hline \multirow[t]{4}{*}{$\begin{array}{c}\mathrm{D} \\
\text { satisfaction }\end{array}$} & & & 37 & & ellipsis \\
\hline & $\begin{array}{c}\mathrm{D} 1 \\
\text { social } \\
\text { satisfaction }\end{array}$ & $\begin{array}{c}\text { D11 } \\
\text { social } \\
\text { satisfaction } \\
\text { survey } \\
\end{array}$ & 20 & $\begin{array}{l}\text { According to the } \\
\text { questionnaire survey }\end{array}$ & ellipsis \\
\hline & $\begin{array}{l}\quad \mathrm{D} 2 \\
\text { residents } \\
\text { effective } \\
\text { complaint } \\
\text { satisfaction }\end{array}$ & $\begin{array}{l}\text { D21 } \\
\text { effective } \\
\text { complaint } \\
\text { rate of } \\
\text { decline }\end{array}$ & 11 & $\begin{array}{l}\text { In accordance with the } \\
\text { relevant management system } \\
\text { and assessment, } \\
\text { comprehensive assessment of } \\
\text { the annual decrease in quantity } \\
\text { / year total complaints }\end{array}$ & ellipsis \\
\hline & $\begin{array}{c}\mathrm{D} 3 \\
\text { industry } \\
\text { satisfaction }\end{array}$ & $\begin{array}{c}\mathrm{D} 31 \\
\text { district level, } \\
\text { municipal or } \\
\text { above } \\
\text { government } \\
\text { awards } \\
\text { (including } \\
\text { collective } \\
\text { Awards) } \\
\end{array}$ & 6 & $\begin{array}{l}\text { Comprehensive evaluation } \\
\text { according to relevant materials }\end{array}$ & ellipsis \\
\hline $\begin{array}{l}\text { The total } \\
\text { score }\end{array}$ & & & 100 & & \\
\hline
\end{tabular}

\section{Evaluation system specification}

Questionnaire survey was used to investigate social satisfaction. On the green landscape, green conservation, trees, lawns, flowers and shrubs beauty pruning, green conservation work group civilization opinions and suggestions 6 maintenance questionnaire, the sample number 500, take on their green coefficients were randomly sampled at one or two, three green green area proportion accounted for dependency maintenance. Calculation of the proportion of green, $26.7 \%$, two green $40 \%$, three green $33.3 \%$, in order to facilitate the operation, according to a level of green space sampling $25 \%$, two green space sampling, $40 \%$, three green sampling $35 \%$ sampling.

\section{Evaluation results}

The use of standards developed by the project and the evaluation index system and grading expert demonstration, through data collection, questionnaire survey and interviews, the objective evaluation of Shanghai city a territorial public green financial expenditure performance, the final score results: the total score is 83 points, the performance rating is "good". Found that the public green space 
maintenance funds are relatively low, green maintenance, especially the classification of street trees maintenance level is single, the implementation of cleaning inspection system is not perfect, resulting in green space environment destroyed several problems.

The evaluation conclusion can reflect the performance of public green space in the year of evaluation, and the index system is scientific and worth popularizing.

\section{Conclusion}

Based on the AHP, the evaluation of the index weight and the development of the scoring rules are adopted to reduce the randomness of the evaluation. Through concrete examples, the scientific and rational of performance budget theory system is analyzed and validated.

The introduction of performance management concept of "customer", "customer service", make public satisfaction, public participation in the evaluation of financial performance evaluation, the change of public green space maintenance quality and effect of the power in the hands of the maintenance department, the traditional model of "internal evaluation".

Due to the particularity of time, data, research methods and performance evaluation, as well as the limitation of research level, there are still many aspects that need to be improved in future research.

\section{Acknowledgements}

Source of the project: The research project of applied talents of design specialty based on the whole practice concept (Project No. Z31011.16.001), a major research project of Sanda University in 2016.

\section{Reference}

[1] storage Sanfen. Analysis of city green space maintenance situation and problems of J. Chinese information construction, 2012,4 (a):60-61

[2] Ma Feng. Research on government budget theory and performance policy [M]. Beijing: China finance and Economics Press, 2008:, 188-191.

[3], Zhu Liyan, Zhang Qiang. The historical evolution of US government performance evaluation [J]. Journal of Xiangtan University: Philosophy and Social Science Edition, 2005 (1): 1-7.

[4] Sheng Mingke, Zhang Yuliang. The basic experience of foreign city government performance management and Its Enlightenment to China J. Gansu Social Sciences, 2012 first: 245-248.

[5] Xu Xin, Ceng Junlin, Yang Bing, et al. Empirical Study on performance evaluation of financial expenditure [J]. Statistics of China, 2005 (3): 40-41.

[6], Lu Jing. Construction of performance evaluation system for financial expenditure [J]. Modern finance and economics, 2005 (5): 15-17.

[7], Xu Chenyang, Wang Huamei. Contents, principles and methods of financial benefit evaluation [J]. Journal of auditing, 2004 (11): 24-25.

[8] Zhu Zhigang. Study on performance evaluation of financial expenditure [M]. Beijing: China finance and Economics Press, 2003: 35.

[9], Guo Yajun, He Yanfang. A comprehensive evaluation of fiscal expenditure in China in 1994-2001 years [J]. Finance and economics research, 2003 (9): 40-43.

[10] Ma Guoxian. The government budget theory and policy research M. Beijing: Chinese finance and Economics Press, 2008: 188-191.

[11], Ouyang, Wahson. Study on performance management of fiscal funds for urban road cleaning in China [J]. Auditing and economic research, 2007 (4): 93-97. 
[12], Ouyang Huasheng, Feng Jia Ning. Study on performance evaluation of urban road maintenance funds [J], Journal of Nanjing Audit University, July 2010, Vol. third, seventh: 1-7.

The Ministry of finance [13]. Management of fiscal expenditure performance evaluation Interim Measures (FB 2009 No. 76) EB/OL. 2009- 06-30.Http: //www.mof.gov.cn /preview/yusuansi /zhengwuxinxi /zhen gceguizhang /200906/t20090630_173338.html.

[14] Chen Yujie. Study on the performance evaluation index system of financial expenditure for urban green construction [J]. Journal of North China Institute of Aerospace Engineering, October 2010, Vol. fifth, Twentieth: 35-37.

[15] Tang Lai, Gu Shu. Social performance evaluation center of Shanghai city public green space distribution: from regional equity to social justice city planning [J]. journal, 2015, (02): 48-56.

[16] Yang Huaiyu. Performance evaluation of landscaping project in University City of Guangzhou. [J]. management information of China, 2016, (15): 196-198.

[17] run Ze. Evaluation method of budget expenditure performance budget performance evaluation system in the education of accounting research J.2008 second: 12-15 